\title{
Delivering below the line in project management - A conceptual exploration
}

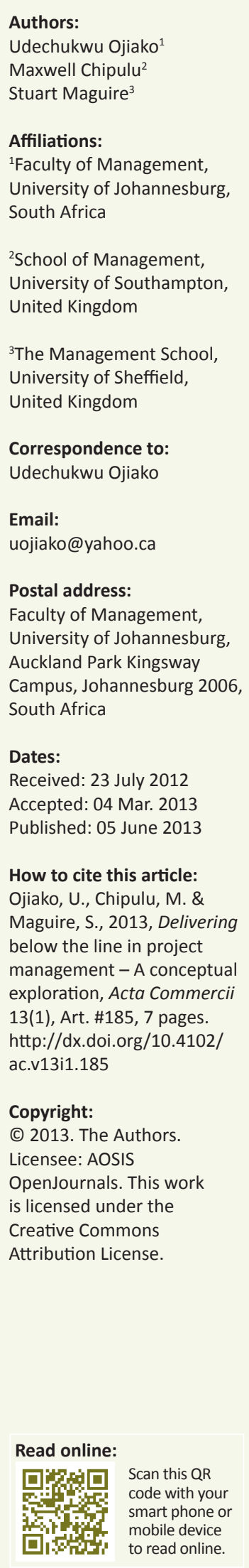

Purpose: In this conceptual paper, the argument is put forward that due to the complexity that characterises most project environments, it is now time to examine alternative notions of project outcomes.

Design/Methodology/Approach: The study is conceptual in nature and draws upon literature on complexity theory, expectations theories and stakeholder theory.

Findings: The paper finds that there is a need to articulate a different assessment of project outcomes than has been traditionally undertaken. Such assessments may emphasise the perceptions of project clients formed through their experience of projects throughout the project lifecycle.

Implications: This paper raises questions on whether the outcomes of projects are best 'measured' or 'assessed'.

\section{Introduction}

Increasingly, it appears that scholars are acknowledging the ever-growing complexity of the business environment (Javidan et al. 2010; Selmier \& Oh 2011; Teagarden 2012). Thus organisations that seek to deal with the complexity challenges of the current business environment are appearing to emphasise the utilisation of 'project management' as a means of ensuring an element of control over an increasingly fluid business environment (Lenfle \& Loch 2010). However, an ideology of control not only suggests the notion of a very static and rigid application of project management concepts, or what Eisenhardt (1985:135), refers to as 'task programmability'; the philosophy is also associated with other characteristics that may constrain the successful delivery of business requirements. One such example is the inference of a relationship between the outcome of a project and management decisions. This paper argues that, without the incorporation of 'complexity', it remains debateable whether such an 'effect and cause' relationship can actually be established.

In response to these challenges, scholars with an interest in project management such as Singh and Singh (2002), Bardyn and Fitzgerald (2005), Thomas and Mengel (2008), Bosch-Rekveldt et al. (2011) and Giezen (2012), have begun to develop an interest in the theories of complexity. Giezen (2012), for example, highlights the need for project managers to drive through 'simplicity' as a means of improving negative project outcomes which are a result of complexity in projects.

\section{Objectives}

The objectives of paper are therefore twofold. First, the paper seeks to examine the notion of 'project outcomes' from the perspective of complexity theory. To facilitate this exploration, literature from expectations theory is examined. To achieve this objective, it becomes necessary to explore the notion of project 'outcomes' and to what extent it is influenced by perceptions. Based on this exploration, the authors take a view from earlier studies (see Bharadwaj et al. 2009), that while project 'measurement' may essentially imply allocations of time, cost and quality dimensions to the outcome of projects, project 'assessment' will involve the formation of either explicit or implicit mental attitudes (Cheesman \& Merikle 1986; Schacter 1990) of the project outcome (Anand et al. 2010). As both 'measurement' and 'assessment' may have two different placements within the control philosophy ('measurement' is more rigidly defined from a time, cost and quality perspective, whilst 'assessment' may be more based on perceptions'), it becomes necessary to articulate either measures or assessments of project outcomes that are embedded in the client's experience.

\section{The current project environment Articulating projects}

To undertake this study, it is first necessary to ensure that a clear understanding is acquired of what distinguishes major projects from other routine activities. The authors argue that four parameters distinguish major projects from routine activities. 
The first differential component of projects is that they are often conceptualised years or - in the case of public sector projects - decades before project implementation commences (see Maguire 2007). The implication is that, in some cases, it is quite difficult to accurately measure the return on project investment because of the intangible benefits that can result from the project. The second major differential between projects and routine activities is that it appears that for projects, in a number of cases, no concerted effort is made to align technical functionalities with business value during the requirements definition stage (Melville et al. 2004). The third project differential is a growing acceptance that the true 'output' of projects is never really known until after the project has been completed or commissioned. For the fourth project differential, various scholars such as Cooke-Davies and Arzymanow (2003) point out that there is a lingering question of whether possible weaknesses in assessment criteria may have contributed to the perception that a high number of projects do not deliver desirable outcomes. Historically, the assessment and measurement of whether a project was a success or not were not based on easily defined attributes, (Icmeli-Tukel \& Rom 1997). Instead, they were based on tightly established criteria that relate to three major assessment parameters; time, cost, and quality - the so-called iron triangle. These parameters, which emerged from studies conducted by Rubin and Seeling (1967), have over the last few years continued to attract criticism not only on whether they represent realistic reflections of project reality but also on their static nature (Blackstone et al. 2009; Lenfle \& Loch 2010). Later studies have also suggested limitations with their utilisation on the basis that they are in fact non-linear concepts that not only vary across and within project stages (Pinto \& Prescott 1988), but which also require the utilisation of different project management tools and techniques to measure them (Patanakul et al. 2010). Thus, concerns over the applicability of the time, cost and quality parameters have generated suggestions that what is needed are dynamic and flexible project assessment criteria (Dvir et al. 2003; Thomas \& Fernández 2008).

\section{Complexity}

The notion of 'complexity' emerged in the 1990s in response to scholarly interest in understanding how organisations may best respond to increasing fluidity in the business environment (Morel \& Ramanujam 1999; Manson 2001; Reitsma 2003). Further evidence of growing interest in complexity in management was the publishing of a special issue in 1999 by Organization Science, the flagship journal of the Institute of Operations Research and the Management Sciences on the application of complexity theory to organisations (see Anderson et al. 1999). Within project management, advocates of the notion of complexity such as Pich et al. (2002) and Cicmil et al. (2009) suggest that complexity represents an avenue along which to simplify and facilitate how interdependencies, size, discontinuities, ambiguities and uncertainties associated with modern projects are understood. The application of complexity theory to project management therefore offers an opportunity for scholarship to re-examine how project outcomes are perceived, particularly when balancing project performance (business and commercial benefits) and project progress (time, cost and quality).

An aspect of complexity which is of interest in this study is deterministic complexity (Spruiell 1993), the roots of which lie within chaos theory. Chaos theory is fundamentally based on cases in behavioural studies where the emergent behaviour does not follow an expected linear path (Lorenz 1993). Described from a qualitative perspective, chaos is presented as subjective and of an individual nature (McBride 2005). Although not necessarily indicating the non-existence of some form of order, chaos suggest that periods of relative calm may be suddenly disrupted by unexpected and random behaviour change (Johnson \& Burton 1994). Applied to project management, chaos serves as a means of acknowledging how quantitative parameters may not necessarily be able to comprehensively 'model' the multi-dimensional nature of the project environment. Chaos also provides a theoretical platform that enables a full appreciation that of the reality that long-term and strategic plans do not necessarily lead to successful project deliveries (Singh \& Singh 2002). In effect, according to Bardyn and Fitzgerald (2005), chaos theory goes further to highlight the fact that projects are not orderly and organised, and that they do not exist in predictable equilibria. Acknowledging the existence of such complexity in projects provides the platform for the earlier highlighted 'effect' and 'cause' relationship between project outcomes and management decisions - in other words, the decision contagion - to be addressed.

\section{Project outcomes}

Projects represent an intensely dynamic aspect of today's global business environment (Lenfle \& Loch 2010). As a result they represent a primary delivery mechanism for achieving business objectives. Evidence for this is provided in numerous works of scholarship; for example, Cheng et al. (2005) and Ruuska and Teigland (2009) have established a direct relationship between the effective utilisation of project management and successful strategy implementation in firms.

The question of how project outcomes are best articulated is important because of the existence of clear conceptual boundaries between criteria utilised to measure projects, in other words, 'success' and 'failure' (Mahring \& Keil 2008; Ika 2009). At the same time, some studies (Joshi et al. 2010) suggest that stakeholders do not apply similar assessments to project outcomes, with some assessing desired outcomes failure from a technical perspective, and others focusing on business outcomes. It becomes important therefore to establish clarity on project outcomes. However, such clarity is difficult to establish as outcomes are ambiguous constructs, dependent on individual judgement that generally seeks to balance needs against expectations. This makes any true articulation of project outcomes partially subjective to the individual perceptions held by different project stakeholders, who may hold different perceptions of project outcomes over the project lifecycle (Ojiako et al. 2012). 
Worthy of note is that over three decades of academic research have provided substantive evidence that the outcomes of numerous projects have failed to meet the expectations of stakeholders, leading to the notion that a substantial number of projects are failures and are subsequently abandoned (Ojiako et al. 2012). Estimates vary, but within the information systems and information technology (IS/IT) world it is not uncommon for upwards of seventy per cent of projects to be categorised as failures (Chen et al. 2009). This therefore implies that, at a very basic level, project outcomes will be assessed from the ability (success) or inability (failure) of stakeholders to acquire expected benefits from specified project outputs. Both concepts are multi-dimensional in nature, however, inevitably being associated with varying connotations for different stakeholders. As Mahring and Keil (2008) and Bharadwaj et al. (2009) point out, because of differing consequences and drivers, 'success' and 'failure' are not mirror images of each other.

\section{Theoretical shift \\ Decision making and judgement}

Over recent years, a substantial amount of research has been undertaken by scholars such as Schwarz (2000) and Blanchette and Richards (2010), who have sought to address the question of perceptions and their impact on decision making and judgement. An understanding of the factors that influence the perceptions of stakeholders and project clients is particularly important for project management, noting that perceptions influence decision making and thus investment strategies. There are two main reasons for this. In the first place, due to the growing complexity of projects, it is fair to suggest that employing project measure criteria rooted firmly in time, cost and quality measures may be too static to effectively assess the outcomes of projects. Secondly, studies (for example Ojiako et al. 2012), do point out that subjective parameters such as social cognition and culture do impact upon perception differences of project outcomes held by individual project managers. Similar to the interest in judgement and decision making that exists within general management, literature shows that within project management there is a developing body of work by scholars such as Clarke (2010) that is now focused on examining the interface between behavioural science and decision making. It is within this area of research that the notion of perceptions, or in other words, mental 'nodes' arises. Perceptions are seen by Freeman (2003) in this case as avenues for individuals to enunciate specific experiences. Perceptions are either explicit, or 'conscious' (Marcel 1983), or implicit and therefore 'subconscious' experiences (Schacter 1990). Both forms of perceptions have the ability to stimulate action (Reber et al. 1998) and generate expressions based on the individual's understanding of the environment. Studies focused on cognitive simplifications (Onken et al. 1985) have also shown that, while experiencing either conscious or unconscious perceptions, individuals are only able to make decisions by reducing complex information to simplified mental models. The implication for decision and judgement within project management is that project stakeholders are only able to make decisions based on limited evaluation of the parameters that impact on the project outcome.

\section{Drawing on 'client' experience}

For over four decades, the relationship between suppliers and clients has been articulated from two dominant perspectives. One relates to client satisfaction as a key critical success factor (Dvir et al. 2003; Lim \& Mohamed 1999), while the other focuses on the supplier-client relationship, following earlier work of Kotler (1972). Thus, for a long period of time, the outcome of projects was dominated by the supplier's perception of what the client either wanted or needed. Overall, as a repositioning of Kotler's initial work began to occur under the notion of 'relationship marketing' (see Booms \& Bitner 1982; Boxer \& Wensley 1986; Judd 1987; Groonroos 1997), it became clear that a rethink of the supplier-client relationship was needed. Within project management, the impact has been felt, for example, in contracting, where projects now emphasise 'best value bid' price as against 'lowest bid' price (Abdelrahman et al. 2008; Oyegoke et al. 2009). This change followed substantial evidence that the 'lowest price' procurement philosophy had consistently failed to deliver construction projects of quality to clients (Conti et al. 2012). In effect, such a transformation within project management may also imply a change of emphasis from a product-led to a service-led discipline (Wikstrom et al. 2009), with serviceled outputs being heavily oriented toward the development and maintenance of relationships between suppliers and clients (now rephrased as 'customers'). To facilitate this shift, researchers such as Ansart and Duymedjian (2006) and Smyth and Edkins (2007) have sought to provide value to the client through the concept of the client experience.

The idea of customer (client) experiences emerged from Harvard (LaSalle \& Britton 2003; Meyer \& Schwager 2007; Parcell 2007) and MIT Sloan studies (Berry et al. 2002; Morgan \& Rao 2003) within relationship marketing and the wider marketing management discipline. As a process (Meyer \& Schwager 2007), client experience has to be lived. It involves an understanding by suppliers (contractors) that emotions will have a major impact on how customers (clients) perceive their interaction with suppliers (Butler 1980) and vice-versa (Johnston 1999). Ultimately it may be argued that, from a project perspective, these experiences will be translated into a client's view of whether or not a project has been successful.

Client experiences do have various attributes. These include their extremely personal and subjective nature (de Kervenoael et al. 2007; Gentile et al. 2007). They are also memorable (Gilmore \& Pine 2002), and consistent enough (Johnston 1999) to ensure that they can be delivered as part of easily recognisable project activities (e.g. daily project communications). Spohrer and Maglio (2007) describe a client experience as an 'intangible experience performed for a client who is also acting in the role of the co-producer that transforms a state of the client'. From their definition, they highlight that client experiences do possess one critical characteristic: 
that the client must be involved in its determination and production of value. Such customer involvement is necessary in order to ensure that the customers' criteria for success (and failure) of projects, which may sometimes not be explicitly stated, are fully captured by the supplier (Prasad et al. 2012). The inability of suppliers to capture such criteria will likely impede their ability to ensure that the benefits of service are fully attained (Spohrer \& Maglio 2007).

\section{Involving clients in the articulation of their experiences}

Client involvement in project management is a wellresearched area (Alvesson et al. 2009; Chen 2011). There are a number of reasons why this is important. In the first place, client involvement enables clients to accept an experience picture which has been jointly produced with the supplier (contractor). Secondly, it also ensures that not only are clients more likely to accept changes that might occur in expected service levels, but also that there is synergy between what experience the supplier (contractor) intends to deliver and the experience the client needs. Finally, although there is disagreement on its viability (Reinartz \& Kumar 2002 2003), involving clients in the articulation of a value-adding client experience has the potential to improve not only client retention, but facilitate the potential of clients actually becoming advocates for the supplier. In industries such as house building with its potential for poor client orientation (Barlow \& Ozaki 2003; Ozaki 2003), such strategies could become the difference between a house building company that survives the current difficulties in the housing market and one that does not.

\section{Synthesising the client experience}

Development of a perspective of client experiences involved synthesising various concepts which are supported by existing literature, the idea being that the development of this understanding of client experiences will enable the achievement of two objectives identified in Smyth and Edkins' (2007) work. One is how an understanding of the wider relationship management area can enable value to be added to project deliveries, and the second is how this study could contribute to the broadening of management intervention in project management markets. The second point is particularly important, as earlier studies, for example by Tseng et al. (1999), Winter (2000), Payne and Frow (2005) and Weinberg et al. (2007), have examined various aspects of customer (client) experience service. However, as none of these studies has focused on client experience within a project environment, the requirement for an understanding of $\mathrm{CE}$ perceptions within a project environment is long overdue.

In order to develop an understanding of the concept of client experience within a project management context, two concepts were synthesised into a single understanding of the client experience. The two concepts are:

- First fundamentals of relationship marketing.

- Psychological theories on client perception lifecycles.

\section{First fundamentals of relationship marketing}

Traditionally, relationship marketing concepts were based on the idea that a 'once in a lifetime contact' and interaction with a client was all that was possible. In such a scenario, suppliers (contractors) engaged with clients without the need to consider the possibility of repeat business. In reality, these concepts, which have roots in marketing ideas first discussed by Philip Kotler (1972), have been rejected by modern marketing thinking. For one, these ideas failed to recognise that the entire factor of client experience and satisfaction is an ongoing process rather than a singular experience. From a project perspective, challenges do exist. For one, there appears to be a suggestion that, in reality, deterioration in client satisfaction can sometimes progressively occur over the course of a project's lifecycle, culminating at the project completion and commissioning stage (Kadefors 2004). If not managed properly, this experience can affect the entire relationship between the client and the contractor, because as the argument goes, 'the last kiss always lingers in one's memory longer than the first one'. As such, the experience gained at project completion has a major impact on the clientcontractor relationship. Suppliers need to pay particular attention to the client relationship because an undesirable experience is unlikely to lead to repeat business. The impact could be damaging, particularly when it is noted that it is more resource-intensive to attract new clients than to retain existing ones.

\section{Psychological theories on client perception lifecycles}

The idea of a client lifecycle is firmly based on organisational lifecycle theories (Dinlersoz \& MacDonald 2009; Kaldasch 2012) and its link to lifelong income streams (Chai et al. 2011). From a project management perspective, the client lifecycle theories suggest that clients will exhibit varying behaviours over different stages of the project lifecycle and that these variations in behaviour will be similar to the case where a customer's tendency to purchase similar products at varying prices does exist (Blattberg \& Deighton 1996). In this context, it is likely that clients will have different perceptions of the same experience, depending not only on the particular stage of the project but also on other factors such as the perceived importance of the project, business outlook, previous experience commissioning similar projects, risk tolerance and the state of the client-contractor relationship.

\section{Delivering client experiences}

Supported by a dramatic growth in service-based revenues (Spohrer \& Maglio 2007), the notion of 'service' dominates the current configuration of the global economy (Nissan et al. 2011). Although this is the case, there are three major hindrances to organisations being able to implement projects that are innovative in terms of service and client experience delivery. One relates to technology, which has reduced considerably the need for human interaction within the service environment. The second relates to the challenges associated with implementing innovative services due to 
their knowledge-intensive nature. The third hindrance to organisations being able to innovate in terms of service and client experience delivery relates to the challenge of coordinating the delivery of a systematic experience, due to the multi-dimensional characteristics of service. For projectoriented organisations, the shift from product-led to serviceled systems will require a dramatic transformation of the industry and profession.

One way organisations are seeking to enhance systematic service (Maglio \& Spohrer 2008) and client experience innovation is through the recently emerging discipline of service science, management and engineering. With its roots in IBM's Almaden Research Centre in San Jose, California, this discipline has a straightforward agenda. This is to bring together supporting theories from a wide range of fields in science, engineering and management (mainly supply chain management) in order to enhance service innovation. This is to be achieved by the use of managed approaches to manage data and facilitate the exchange of knowledge (Paton \& McLaughlin 2008). Achieving this objective also requires a significant project management input, particularly as successful delivery of innovative services means that companies need to emphasise the excellence of their implementation and planning. Information from these data is expected to not only enhance the delivered experience, but also on occasions that this experience is not delivered, will seek to present a picture to explain why this is the case.

One crucial element of this new discipline is the recognition that the integrated disciplines must successfully incorporate not only management, but also other disciplines and areas that may possess the capabilities that will become relevant to the service and client experience (Maglio \& Spohrer 2008).

Notably, a supplier's (contractor's) ability to fully anticipate their client's outlook on experiences is likely to enhance the competitiveness of any project-oriented organisation. For one, it enables the supplier to obtain an understanding of the unspoken, personal and subjective prejudices that clients possess. Obtaining this knowledge is a key competitive weapon due to its 'hidden' nature. This attribute means that competitors are unlikely to be in possession of this knowledge. This seriously hinders their ability to imitate key supplier experience strategies that might attract or retain clients. The reality, however, is that the ability of projectoriented organisations to exceed or at least deliver expected client experiences faces numerous challenges. One of these challenges relates to project management and organisational competencies (Sense 2007) and their impact on the ability of contractors to deliver and exceed client experience expectations. Service science represents an agenda for ensuring that these key competencies are harnessed in a way that supports the delivery of client experiences.

\section{Conclusions}

In 2006, the 'rethinking project management' agenda was launched. Funded by the UK's Engineering and Physical Sciences Research Council (EPSRC), the initiative focused on developing a research agenda aimed at driving the discipline of project management beyond its existing conceptual foundations (Winter et al. 2006). The main ethos of the rethinking project management agenda was not simply to emphasise the much broader discipline of project management but, according to scholars such as Sauer and Reich (2009), to ensure that the project management profession focused on ensuring that project management practitioners developed appropriate personal qualities and mind-set that will facilitate such rethinking.

A key message which has emerged from the rethinking agenda is the need for project management to remain a relevant management tool within the business environment. To achieve this objective, scholars such as Cicmil et al. (2006) suggest the need for emphasis on practitioners' lived experiences. In response to this call, this paper had two objectives: the first was to examine 'project outcomes' from a complexity perspective, while the second was to examine how the shift in emphasis from relational contracting to relationship management has impacted on the outcome of projects. Drawing upon extant literature, the study found in response to the first objective that, from a complexity perspective, project outcomes were best articulated from a perception perspective, and more specifically, such perceptions were those of the clients, which had been formed during the project lifecycle. In terms of the second objective, the study found that since client and supplier relationships were more likely to be forged over a period that extended across a number of projects, there was a need for suppliers to focus on client experiences, particularly at the project completion stage. Thus, from a managerial perspective, this conceptual study could serve as a sense-making tool to practitioners seeking to conceptualise the delivery of projects in complex business environments.

As is generally expected, this conceptual study is not without limitations. In the first place, the study is largely discursive and reflective, seeking to establish a relationship between management concepts in a manner not previously undertaken. Such an approach - whilst novel - runs the risk of construct bias. This limitation hence provides the basis for future research which may for example seek to articulate the themes and concepts employed in the study empirically. An emergent model from the empirical study is likely to ensure the provision of a clearer set of relationships between the concepts employed in this study.

\section{Acknowledgments Competing interests}

The authors declare that they have no financial or personal relationship(s) which may have inappropriately influenced them in writing this paper.

\section{Authors' contributions}

U.O. (University of Johannesburg), M.C. (University of Southampton) and S.M. (University of Sheffield) all made equal conceptual contributions that led to the development of this paper. 


\section{References}

Abdelrahman, M., Zayed, T. \& Elyamany, A., 2008, 'Best-value model based on projectspecific characteristics', Journal of Construction Engineering and Management 134(3), 179-188. http://dx.doi.org/10.1061/(ASCE)0733-9364(2008)134:3(179)

Alvesson, M., Karreman, D., Sturdy, A. \& Handley, K., 2009, 'Unpacking the client(s): Constructions, positions and client-consultant dynamics', Scandinavian Journal of Management 25(3), 253-263.

Anand, G., Ward, P. \& Tatikonda, M., 2010, 'Role of explicit and tacit knowledge in Six Sigma projects: An empirical examination of differential project success' Journal of Operations Management 28(4), 303-315. http://dx.doi.org/10.1016/j. jom.2009.10.003

Anderson, P., Meyer, A., Eisenhardt, K., Carley, K. \& Pettigrew, A., 1999, 'Introduction to the special issue: Applications of complexity theory to organization science' Organization Science 10(3), 233-236. http://dx.doi.org/10.1287/orsc.10.3.233

Ansart, S. \& Duymedjian, R., 2006, 'What relationship does the French car industry have with its clients? The customer-experience concept applied to the websites of two manufacturers', International Journal of Automotive Technology and Management 6(1), 59-79. http://dx.doi.org/10.1504/IJATM.2006.008936

Bardyn, J. \& Fitzgerald, D., 2005, 'Chaos theory and project management: A perspective on managing the complex project', in M.R. Lissack \& H.P. Gunz (eds.), Managing complexity in organizations: A view in many directions, new edn., pp. 246-258, Information Age Publishing, Charlotte.

Barlow, J. \& Ozaki, R., 2003, 'Achieving customer focus in private house building: Current practice and lessons from other industries', Housing Studies 18(1), 87101. http://dx.doi.org/10.1080/0267303032000076858

Berry, L., Carbone, L. \& Haeckel, S., 2002, Managing the total customer experience. MIT Sloan Management Review 43, 85-89.

Bharadwaj, A., Keil, M. \& Mahring, M., 2009, 'Effects of information technology failures on the market value of firms', Journal of Strategic Information Systems 18(2), 66-79. http://dx.doi.org/10.1016/j.jsis.2009.04.001

Blackstone, J., Cox, J. \& Schleier, J., 2009, 'A tutorial on project management from a theory of constraints perspective', International Journal of Production Research 47(24), 7029-7046. http://dx.doi.org/10.1080/00207540802392551

Blanchette, I. \& Richards, A., 2010, 'The influence of affect on higher level cognition: A review of research on interpretation, judgement, decision making and reasoning', Cognition \& Emotion 24(4), 561-595. http://dx.doi. org/10.1080/02699930903132496

Blattberg, R. \& Deighton, J., 1996, 'Manage marketing by the customer equity test', Harvard Business Review July-August, 136-144.

Booms, B. \& Bitner, M., 1982, 'Marketing strategies and organisation structures for service firms', in J.H. Donnelly \& W.R. George (eds.), Marketing of Services, pp. 47-51, American Marketing Association, Chicago.

Bosch-Rekveldt, M., Jongkind, Y., Mooi, H., Bakker, H. \& Verbraeck, A., 2011 'Grasping project complexity in large engineering projects: The TOE (technical, organizational and environmental) framework', International Journal of Project Management 29(6), 728-739. http://dx.doi.org/10.1016/j.ijproman.2010.07.008

Boxer, P. \& Wensley, J., 1986, 'The need for middle-out development of marketing strategy', Journal of Management Studies 32, 189-204. http://dx.doi. org/10.1111/j.1467-6486.1986.tb00419.x

Butler, R., 1980, 'User satisfaction with a service: An approach from power and task characteristics', Journal of Management Studies 17, 1-18. http://dx.doi. org/10.1111/j.1467-6486.1980.tb00394.x

Chai, J., Horneff, W., Maurer, R. \& Mitchell, O., 2011, 'Optimal portfolio choice over the life cycle with flexible work, endogenous retirement, and lifetime payouts', Review of Finance 15(4), 875-907. http://dx.doi.org/10.1093/rof/rfr016

Cheesman, J. \& Merikle, P., 1986, 'Distinguishing conscious from unconscious perceptual processes', Canadian Journal of Psychology 40, 343-367. http://dx.doi. org/10.1037/h0080103

Chen, C., 2011, 'Managing projects from a client perspective: The concept of the meetings-flow approach', International Journal of Project Management 29(6), 671-686. http://dx.doi.org/10.1016/j.ijproman.2010.07.007

Chen, C., Law, C. \& Yang, S., 2009, 'Managing ERP implementation failure: A project management perspective', IEEE Transactions on Engineering Management 56(1) 157-170. http://dx.doi.org/10.1109/TEM.2008.2009802

Cheng, M., Dainty, A. \& Moore, D., 2005, 'What makes a good project manager?' Human Resource Management Journal 15(1), 25-37. http://dx.doi. org/10.1111/j.1748-8583.2005.tb00138.x

Cicmil, S., Williams, T., Thomas, J. \& Hodgson, D., 2006, 'Rethinking project management: Researching the actuality of projects', International Journal

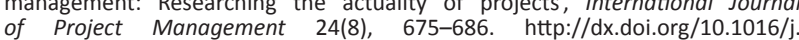
ijproman.2006.08.006

Cicmil, S., Cooke-Davies, T., Crawford, L. \& Richardson, K., 2009, Exploring the complexity of projects: Implications of complexity theory for project management practice, Project Management Institute Publishing, Newtown Square.

Clarke, N., 2010, 'Emotional intelligence and its relationship to transformational leadership and key project manager competences', Project Management Journal 28(3), 1-10.

Conti, P., De Giovanni, L. \& Naldi, M., 2012, 'A rank-and-compare algorithm to detect abnormally low bids in procurement auctions', Electronic Commerce Research and Applications 11(2), 192-203. http://dx.doi.org/10.1016/j.elerap.2011.12.008
Cooke-Davies, T. \& Arzymanow A., 2003, 'The maturity of project management in different industries: an investigation into variations between project management models', International Journal of Project Management 21(6), 471-478. http:// models, International Journal of Project Man
dx.doi.org/10.1016/S0263-7863(02)00084-4

De Kervenoael, R., Soopramanien, D., Hallsworth, A. \& Elms, J., 2007, 'Personal privacy as a positive experience of shopping - An illustration through the case of online grocery shopping', International Journal of Retail and Distribution Management 35(7), 583-599. http://dx.doi.org/10.1108/09590550710755958

Dinlersoz, E. \& MacDonald, G., 2009, 'The industry life-cycle of the size distribution of firms', Review of Economic Dynamics 12(4), 648-667. http://dx.doi.org/10.1016/j. red.2009.01.001

Dvir, D., Lipovetsky, S., Shenhar, A. \& Tishler, A., 2003, 'What is really important for project success? A multidimensional analysis of project management variables' International Journal of Management and Decision Making 4(4), 382-404. http:// dx.doi.org/10.1504/IJMDM.2003.004001

Eisenhardt, K., 1985, 'Control: Organizational and economic approaches', Management Science 31, 134-149. http://dx.doi.org/10.1287/mnsc.31.2.134

Freeman, W., 2003, 'A neurobiological theory of meaning in perception. Part 1 , Information and meaning in nonconvergent and nonlocal brain dynamics' International Journal of Bifurcation and Chaos 13,2493-2511. http://dx.doi. org/10.1142/S0218127403008144

Gentile, C., Spiller, N. \& Noci, G., 2007, 'How to sustain the customer experience: An overview of experience components that co-create value with the customer',
European Management Journal 25(5), 395-410. http://dx.doi.org/10.1016/j. European Managem
emj.2007.08.005

Giezen, M., 2012, 'Keeping it simple? A case study into the advantages and disadvantages of reducing complexity in mega project planning', International
Journal of Project Management 30(7), 781-790. http://dx.doi.org/10.1016/j. Journal of Project Mand

Gilmore, J. \& Pine, J., 2002, 'Customer experience places: the new offering frontier', Strategy and Leadership 30(4), 4-11. http://dx.doi. offering frontier', Strategy and
org/10.1108/10878570210435306

Groonroos, C., 1997, 'From marketing mix to relationship marketing', Management Decision 35, 322-339. http://dx.doi.org/10.1108/00251749710169729

Icmeli-Tukel, O. \& Rom, W., 1997, 'Ensuring quality in resource constrained project scheduling', European Journal of Operational Research 103(3), 483-496. http:// dx.doi.org/10.1016/S0377-2217(96)00305-0

Ika, L., 2009, 'Project success as a topic in project management journals', Project Management Journal 40(4), 6-19. http://dx.doi.org/10.1002/pmj.20137

Javidan, M., Teagarden, M \& Bowen, D., 2010, 'Making it overseas', Harvard Business Review, 109-113.

Johnson, J. \& Burton, B., 1994, 'Chaos and complexity theory for management Caveat emptor', Journal of Management Inquiry 3(4), 320-328. http://dx.doi. org/10.1177/105649269434005

Johnston, R., 1999, 'Service transaction analysis: assessing and improving the customer's experience', Managing Service Quality 9(2), 102-109. http://dx.doi. org/10.1108/09604529910257876

Joshi, K., Kuhn, K. \& Niederman, F., 2010, 'Excellence in IT Consulting: Integrating Multiple Stakeholders' Perceptions of Top Performers', IEEE Transaction on Engineering Management 57(4), 589-606. http://dx.doi.org/10.1109/ TEM.2010.2040742

Judd, V., 1987, 'Differentiate with the 5th P: People', Industrial Marketing Management 16, 241-247. http://dx.doi.org/10.1016/0019-8501(87)90032-0

Kadefors, A., 2004, 'Trust in project relationships - Inside the black box', Internationa Journal of Project Management 22(3), 175-182. http://dx.doi.org/10.1016/ S0263-7863(03)00031-0

Kaldasch, J., 2012, 'Evolutionary model of the growth and size of firms', Physica A Statistical Mechanics and its Applications 391(14), 3751-3769. http://dx.doi. org/10.1016/j.physa.2012.01.027

Kotler, P., 1972, 'A generic concept of marketing', Journal of Marketing 36(2), 46-54. http://dx.doi.org/10.2307/1250977

LaSalle, D. \& Britton, T., 2003, Priceless: Turning ordinary products into extraordinary experiences, Harvard Business School Press, Boston.

Lenfle, S. \& Loch, C., 2010, 'Lost roots: How project management came to emphasize control over flexibility and novelty', California Management Review 53(1), 32-55. http://dx.doi.org/10.1525/cmr.2010.53.1.32

Lim, C. \& Mohamed, M., 1999, 'Criteria of project success: an exploratory reexamination', International Journal of Project Management 17, 243-248. http:// dx.doi.org/10.1016/S0263-7863(98)00040-4

Lorenz, E., 1993, The Essence of Chaos, UCL Press, London. http://dx.doi. org/10.4324/9780203214589

Maglio, P. \& Spohrer, J., 2008, 'Fundamentals of service science', Journal of the Academy of Marketing Science 36, 18-20. http://dx.doi.org/10.1007/s11747007-0058-9

Maguire, S., 2007, 'Reviewing 25 years of national information systems in the NHS' Public Money and Management 27(2), 135-140. http://dx.doi.org/10.1111/ j.1467-9302.2007.00569.x

Mahring, M. \& Keil, M., 2008, 'Information technology project escalation: A process model', Decision Sciences 39(2), 239-272. http://dx.doi.org/10.1111/j.15405915.2008.00191.x

Manson, S., 2001, 'Simplifying complexity: A review of complexity theory', Geoforum 32(3), 405-414. http://dx.doi.org/10.1016/S0016-7185(00)00035-X 
Marcel, A., 1983, 'Conscious and unconscious perception: An approach to the relations between phenomenal experience and perceptual processes', Cognitive relations between phenomenal experience and perceptual processes, Cog
Psychology 15, 238-300. http://dx.doi.org/10.1016/0010-0285(83)90010-5

McBride, N., 2005, 'Chaos theory as a model for interpreting information systems in organizations', Information Systems Journal 15, 233-254. http://dx.doi. org/10.1111/j.1365-2575.2005.00192.x

Melville, N., Kraemer, K. \& Gurbaxani, V., 2004, 'Information technology and organizational performance: An integrative model of it business value review: Information technology and organizational performance: an integrative model of it business value', MIS Quarterly 28(2), 283-322.

Meyer, C. \& Schwager, A., 2007, 'Understanding customer experience', Harvard Business Review 85, 116-126.

Morel, B. \& Ramanujam, R., 1999, 'Through the looking glass of complexity: The dynamics of organizations as adaptive and evolving systems', Organization Science 10(3), 278-293. http://dx.doi.org/10.1287/orsc.10.3.278

Morgan, I. \& Rao, J., 2003, 'Making routine customer experiences fun', MIT Sloan Management Review 45, 93-95.

Nissan, E., Galindo, M.-A., \& Mendez, M., 2011, 'The future of services in a globalized economy', The Services Industry Journal 31(1), 59-78. http://dx.doi.org/10.1080 /02642069.2010.485195

Ojiako, U., Chipulu, M., Gardiner, P., Williams, T., Anantatmula, V., Mota, C., Maguire, S., Shou, Y., Nwilo, P. \& Peansupap, V., 2012, Cultural imperatives in perception of project failure, Project Management Institute Publishing, Newtown Square.

Onken, J., Hastie, R. \& Revelle, W., 1985, 'Individual differences in the use of simplification strategies in a complex decision-making task', Journal of Experimental Psychology: Human Perception and Performance 11(1), 14-27. hxperimental Psychology: Human Perception and Performance

Oyegoke, A., Dickinson, M., Khalfan, M., McDermott, P. \& Rowlinson, S., 2009, 'Construction project procurement routes: an in-depth critique', International Journal of Managing Projects in Business 2(3), 338-354. http://dx.doi. ournal of Managing Projects
org $10.1108 / 17538370910971018$

Ozaki, R., 2003, 'Customer-focused approaches to innovation in house building', Construction Management and Economics 21(6), 557-564. http://dx.doi. org/10.1080/0144619032000134093

Parcell, D., 2007, 'Understanding customer experience', Harvard Business Review 85(6), 137-137.

Patanakul, P., Lewwongcharoen, B. \& Milosevic, D., 2010, 'An empirical study on the use of project management tools and techniques across project life-cycle and their impact on project success', Journal of General Management 35(3), 41-65.

Paton, R. \& McLaughlin, S., 2008, 'Services innovation: Knowledge transfer and the supply chain', European Management Journal 26, 77- 83. http://dx.doi. org/10.1016/j.emj.2008.01.004

Payne, A. \& Frow, P., 2005, 'A strategic framework for customer relationship management', Journal of Marketing, 69, 167-176. http://dx.doi.org/10.1509/ jmkg.2005.69.4.167

Pich, M., Loch, C. \& De Meyer, A., 2002, 'On uncertainty and complexity in project management', Management Science 48(8), 1008-1023. http://dx.doi. org/10.1287/mnsc.48.8.1008.163

Pinto, J. \& Prescott, J., 1988, 'Variations in critical success factors over the stage in the project life cycle', Journal of Management 14, 5-18. http://dx.doi. org/10.1177/014920638801400102

Prasad, G., Reddi, K., Sai, V., Prasad, P. \& Kumar, R., 2012, 'A study on how a project manager can deliver a quality product with reference to the requirements', International Journal of Advanced Research in Computer Science and Electronics Engineering 1(7), 204-212.

Reber, R., Winkielman, P. \& Schwarz, N., 1998, 'Effects of perceptual fluency on affective judgments', Psychological Science 9, 45-48. http://dx.doi.org/10.1111/14679280.00008

Reinartz, W. \& Kumar, V., 2002, 'The mismanagement of customer loyalty', Harvard Business Review, 86-94.
Reinartz, W. \& Kumar, V., 2003, 'The impact of customer relationship characteristics on profitable lifetime duration', Journal of Marketing 67(1), 77-99. http://dx.doi. org/10.1509/jmkg.67.1.77.18589

Reitsma, F., 2003, 'A response to simplifying complexity', Geoforum 34(1), 13-16. http://dx.doi.org/10.1016/S0016-7185(02)00014-3

Rubin, I. \& Seeling, W., 1967, 'Experience as a factor in the selection and performance of project managers', IEEE Transactions on Engineering Management 14, 131-134.

Ruuska, I. \& Teigland, R., 2009, 'Ensuring project success through collective competence and creative conflict in public/private partnerships - A case study of Bygga Villa, a Swedish triple helix e-government initiative', International Journal of Project Management 27(4), 323-334. http://dx.doi.org/10.1016/j ijproman.2008.02.007

Sauer, C. \& Reich, B., 2009, 'Rethinking IT project management: Evidence of a new mindset and its implications', International Journal of Project Management 27(2), 182-193. http://dx.doi.org/10.1016/j.ijproman.2008.08.003

Schacter, D., 1990, 'Introduction to implicit memory: Multiple perspectives', Bulletin of the Psychonomic Society 28, 338-340.

Schwarz, N., 2000, 'Emotion, cognition, and decision making', Cognition \& Emotion 14(4), 433-440. http://dx.doi.org/10.1080/026999300402745

Selmier, W. \& Oh, C., 2012, 'International business complexity and the internationalization of languages', Business Horizons 55(2), 189-200. http:// dx.doi.org/10.1016/j.bushor.2011.11.006

Sense, A., 2007, 'Structuring the project environment for learning', Internationa Journal of Project Management 25(4), 405-412. http://dx.doi.org/10.1016/j. ijproman.2007.01.013

Singh, H. \& Singh, A. 2002, 'Principles of complexity and chaos theory in project execution: A new approach to management', Cost Engineering 44(12), 23-33.

Smyth, H. \& Edkins A., 2007, 'Relationship management in the management of PFI/ PPP projects in the UK', International Journal of Project Management 25(3), 232240. http://dx.doi.org/10.1016/j.ijproman.2006.08.003

Spohrer, J. \& Maglio, P., 2007, The emergence of service science: Toward systematic service innovations to accelerate co-creation of value, viewed 11 February 2012 from http://www-304.ibm.com/jct09002c/university/ scholars/skills/ssme/ from http://ww

Spruiell, V., 1993, 'Deterministic chaos and the sciences of complexity: Psychoanalysis in the midst of a general scientific revolution', Journal of the American Psychoanalytic Association 41(1), 3-44.

Teagarden, M., 2012, 'Global business complexity', Thunderbird International 54(5), 607-608. http://dx.doi.org/10.1002/tie.21487

Thomas, G. \& Fernandez, W., 2008, 'Success in IT projects: A matter of definition?' International Journal of Project Management, 26(7), 733-742. http://dx.doi. org/10.1016/j.ijproman.2008.06.003

Thomas, J. \& Mengel, T., 2008, 'Preparing project managers to deal with complexity - Advanced project management education', International Journal of Project Management 26(3), 304-315. http://dx.doi.org/10.1016/j.ijproman.2008.01.001

Tseng, M., Qinhai, M. \& Su, C., 1999, 'Mapping customers' service experience for operations improvement', Business Process Management Journal 5(1), 50-64. http://dx.doi.org/10.1108/14637159910249126

Weinberg, B., Parise, S. \& Guinan, P., 2007, 'Multichannel marketing: Mindset and program development', Business Horizons 50, 385-394. http://dx.doi. org/10.1016/j.bushor.2007.04.002

Wikstrom, K., Hellstrom, M., Artto, K., Kujala, J. \& Kujala, S., 2009, 'Services in projectbased firms - Four types of business logic', International Journal of Project Management 27(2), 113-122. http://dx.doi.org/10.1016/j.ijproman.2008.09.008

Winter, R., 2000, 'A framework for customer relationship management', California Management Review 43, 89-105. http://dx.doi.org/10.2307/41166102

Winter, M., Smith, C., Morris, P. \& Cicmil, S., 2006, 'Directions for future research in project management: the main findings of a UK government funded research network', International Journal of Project Management 24(8), 638-649. http:// dx.doi.org/10.1016/j.jproman.2006.08.009 